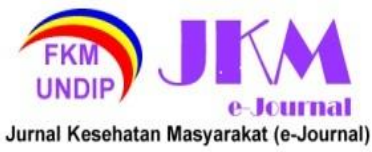

JURNAL KESEHATAN MASYARAKAT (e-Journal)

Volume 10, Nomor 1, Januari 2022

ISSN: 2715-5617 / e-ISSN: 2356-3346

http://ejournal3.undip.ac.id/index.php/jkm

\title{
GAMBARAN EPIDEMIOLOGI COVID-19 DAN HUBUNGANNYA DENGAN PERILAKU PENCEGAHAN DI KOTA SEMARANG
}

\author{
Zaimatun Nabilah ${ }^{1 *}$ \\ ${ }^{1}$ Fakultas Ilmu Keolahragaan, Universitas Negeri Semarang, Sekaran, Gunungpati, Semarang, Indonesia 50229 \\ *Corresponding author: zainabilah27@gmail.com
}

\begin{abstract}
The COVID-19 pandemic caused by the SARSCoV-2 virus in 2019 had caused 2 million deaths in 220 countries in the world until March 2021. The city of Semarang is ranked first in Central Java with 72,329 confirmed cases, with sufferers dominated by men (52.6\%) and women (47.4\%), and the age range mostly suffered by productive age (20-54 years) as many as 1,142 people (52\%).Health behavior according to L. Green is influenced by several factors; predisposing, reinforcing, and enabling. The purpose of this study was to determine the faetures of the epidemiology of COVID-19 and its relationship with preventive behavior in the city of Semarang. The type of research is observational analytic and cross sectional design with simple random sampling technique. The research sample is 55 respondents. Data were analyzed by Chi Square statistical test and logistic regression. The results showed that the factors associated with COVID-19 prevention behavior were gender $(p<0.05 ; P R=2.89)$, level of knowledge $(p<0.01 ; P R=4.57)$, and attitude of prevention $(p<0.05$; $p<0.05 ; P R=3.53)$. After controlling for other variables, the most influential factor on COVID-19 prevention behavior was the level of knowledge ( $p=0.007)$. There is a relationship between gender, level of knowledge, and prevention attitudes with COVID-19 prevention behavior, but there is no relationship between age, employment status, education level, role of health services, vaccination status, history of social contact with COVID-19 patients. 19 with COVID-19 preventive behavior. The advice for this research is to always follow the development of information from trusted sources regarding COVID-19 and always obey health protocols.
\end{abstract}

Keywords: COVID-19, epidemiological description, preventive behavior

\section{PENDAHULUAN}

Pandemi COVID-19 (Coronavirus Disease 2019) yang disebabkan oleh virus SARSCoV-2 (Severe Acute Respiratory Syndrome Coronavirus2) menjadi peristiwa yang mengancam kesehatan masyarakat, menyerang sistem pernapasan dan menyebabkan penyakit mulai dari flu biasa hingga sindrom pernapasan akut yang parah (SARS). ${ }^{1}$ Hingga 12 Maret 2021, lebih dari 118 juta kasus yang dikonfirmasi di 220 negara dan lebih dari 2 juta kematian telah dilaporkan. ${ }^{2}$ Per 14 Juli 2021, Indonesia menempati peringkat ke 15 dari 221 dengan total konfirmasi lebih dari 2,6 juta kasus. ${ }^{3}$ Semarang dengan jumlah kasus konfirmasi 27,514 kasus menempati urutan tertinggi di wilayah Jawa Tengah. ${ }^{4}$ Guna mengendalikan penularan kasus COVID-19, beberapa tindakan telah dilakukan oleh Pemerintah Kota Semarang, seperti; melakukan edukasi keliling mengenai protokol kesehatan pencegahan COVID-19 setiap hari yang dilakukan oleh Puskesmas, menyediakan sarana prasarana berupa fasilitas tempat cuci tangan di tempat umum seperti pusat perbelanjaan, menayangkan iklan layanan masyarakat dalam mengimbau untuk selalu menaati protokol kesehatan di beberapa rambu lalu lintas, dan masih banyak lagi. Tindakan protokol kesehatan yang ditetapkan oleh WHO dan Kementerian Kesehatan RI tidak akan berjalan sebelum masyarakat dibekali dengan pengetahuan, sikap dan keterampilan yang baik dalam pelaksanaannya. Pengetahuan yang baik, akan mendorong sikap dan perilaku positif, seperti perilaku kesehatan yang berupa perilaku pencegahan COVID-19. ${ }^{5}$

Perilaku kesehatan menurut L. Green, dipengaruhi dan ditentukan oleh tiga faktor yaitu faktor predisposisi (predisposing factor), faktor pemungkin (enabling factor), dan faktor pendorong/penguat (reinforcing factor). ${ }^{6}$ Jika dilihat dari faktor predisposisi, masyarakat memiliki faktor sosiodemografi seperti perbedaan umur, jenis kelamin, tingkat pendidikan, pekerjaan, tingkat pengetahuan, serta daerah asal. Gambaran karakteristik sosiodemografi tersebut dapat memengaruhi perilaku masyarakat serta outcome dari kesehatan masyarakat. ${ }^{7}$ Faktor pemungkin (enabling factor) juga berperan dalam terbentuknya perilaku pencegahan COVID-19, seperti status vaksinasi. Saat ini, vaksin untuk SARS-CoV-2 sudah tersedia dan telah diedarkan di masyarakat Indonesia. Disisi lain, pemerintah tetap menghimbau supaya masyarakat tidak mengesampingkan protokol kesehatan dalam beraktivitas dimanapun dan kapanpun mengingat virus ini masih bermutasi dan belum diketahui dampak jangka panjangnya dari mutasi ini. ${ }^{8}$

Penelitian sebelumnya yang dilakukan oleh Prihati menunjukkan tidak ada hubungan yang signifikan antara usia responden, jenis kelamin, dan jenis pekerjaan terhadap perilaku dalam pencegahan COVID-19. ${ }^{9}$ Disisi lain, pada penelitian Shamshiripour, Rahimi, Shabanpour, \& 


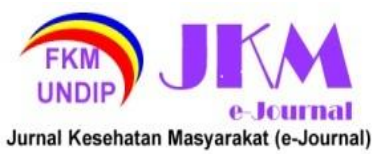

Mohammadian (2020) sebagian responden (5\%) melaporkan mereka melakukan kontak erat dengan kasus konfirmasi COVID-19 dan berpotensi terjangkit infeksi karena mengalami gejala (3\%) setelah melakukan kontak. ${ }^{10}$ Kontak erat, termasuk tinggal satu rumah dengan pasien COVID-19 dan riwayat perjalanan ke area terjangkit dapat menjadikan seseorang terkena infeksi COVID-19. ${ }^{2}$ Berdasarkan studi pendahuluan melalui data Dinas Kesehatan Kota Semarang per 19 Juli 2021, kasus konfirmasi aktif COVID-19 lebih banyak diderita oleh laki-laki sebanyak 1050 orang $(52,6 \%)$ dibandingkan perempuan sebanyak 948 orang $(47,4 \%)$. Menurut persebaran kelompok usia, usia produktif (20-54 tahun) menyumbang angka kasus konfirmasi aktif paling banyak (52\%) dibanding kelompok usia lainnya. Penelitian mengenai gambaran epidemiologi COVID-19 sudah banyak dilakukan, namun yang menghubungankan keterbaruan variabel seperti status vaksinasi dan riwayat kontak sosial dengan pasien konfirmasi aktif dengan perilaku pencegahan COVID-19 belum banyak diteliti. Untuk itu, peneliti tertarik melakukan penelitian mengenai gambaran epidemiologi COVID-19 dan hubungannya dengan perilaku pencegahan di Kota Semarang.

\section{METODE PENELITIAN}

Penelitian ini merupakan penelitian analitik observasional dengan menggunakan metode penelitian kuantitatif dengan pendekatan cross sectional study. Pengumpulan data dilakukan dengan penyebaran angket melalui google form. Populasi penelitian adalah kasus konfirmasi COVID-19 di Kota Semarang. Sampel penelitian diambil menggunakan teknik simple random sampling sebanyak 55 responden. Kuesioner instrumen terdiri dari 4 bagian; identitas responden, variabel pengetahuan, variabel sikap, dan variabel perilaku. Variabel identitas responden berisi tentang usia, jenis kelamin, status pekerjaan, tingkat pendidikan, lokasi tempat tinggal, masa inkubasi, dan status vaksinasi. Variabel tingkat pengetahuan, sikap, dan perilaku terdiri dari masing-masing 10 pernyataan pengetahuan, 9 pernyataan sikap, dan 8 pertanyaan perilaku yang mengandung unsur favorable dan unfavorable. Pernyataan pada variabel pengetahuan diadopsi dari penelitian sebelumnya yang mengadaptasi dari sumber RCCE WHO dengan Cronbach alpha 0.65 (Azlan et al., 2020). Pernyataan pada variabel sikap dan perilaku diadopsi dan dimodifikasi dari Panduan Survei oleh WHO guna memantau pengetahuan, persepsi risiko, perilaku pencegahan dan kepercayaan untuk menginformasikan tanggapan wabah pandemi dengan nilai Cronbach alpha sikap 0,799 dan perilaku 0,746. ${ }^{11}$ Analisis data dilakukan secara univariat, bivariat menggunakan uji Chi-Square taraf signifikasi $95 \%$, dan multiariabel.

\section{HASIL DAN PEMBAHASAN GAMBARAN UMUM \\ Gambaran Epidemiologi Berdasarkan Karakteristik Tempat \\ Kota Semarang merupakan ibukota} Provinsi Jawa Tengah yang berada pada perlintasan jalur jalan pantai utara Pulau Jawa, menghubungkan Jawa bagian timur dan Jawa bagian barat. Posisi koordinat Kota Semarang terletak diantara $109^{\circ} 35^{\prime}-110^{\circ} 50^{\prime}$ bujur timur dan $6^{\circ} 50^{\prime}-7^{\circ} 10^{\prime}$ lintang selatan. Luas wilayah Kota Semarang adalah $373,70 \mathrm{~km}^{2}$. Memiliki 16 kecamatan dan 177 kelurahan dengan jumlah penduduk sebanyak 1,68 juta jiwa. Terdapat 37 Puskesmas yang tersebar merata dan berada dibawah naungan Dinas Kesehatan Kota Semarang. Dengan luas wilayah kerja dan banyaknya jumlah penduduk di Kota Semarang, terdapat data 5 penyakit terbesar tahun 2020 antara lain hipertensi, ISPA, faringitis akut, diabetes mellitus, gastritis dan duodenitis. Tingkat kepadatan penduduk 5 tertinggi terdapat pada Kecamatan Candisari, Gayamsari, Semarang Utara, Semarang Selatan, dan Pedurungan. Salah satu penyakit yang saat ini populer di Kota Semarang adalah COVID-19. Data kasus konfirmasi COVID-19 per 29 Juli 2021 di Kota Semarang menduduki peringkat pertama di Jawa Tengah yaitu sebanyak lebih dari 78 ribu kasus konfirmasi yang terdiri dari konfirmasi aktif, konfirmasi sembuh, dan konfirmasi meninggal. Berdasarkan data dari Dinas Kesehatan Kota Semarang, tingkat fatalitas kasus (CFR) akibat COVID-19 sebesar 7,31\%, angka ini lebih tinggi daripada tingkat fatalitas kasus secara nasional yaitu $2,81 \%$. Kasus tertinggi hingga terendah berturut-turut pada kecamatan Pedurungan 196 kasus (13\%), kecamatan Tembalang sebanyak 194 kasus (13\%), kecamatan Semarang Barat sebanyak 160 kasus (11\%), kecamatan Banyumanik 134 kasus (9\%), kecamatan Ngaliyan sebanyak 131 kasus (9\%), Semarang Selatan sebanyak 97 kasus (6\%0, kecamatan Candisari sebanyak 85 kasus (6\%), kecamatan Semarang Timur sebanyak 81 kasus (5\%0, kecamatan Genuk sebanyak 77 kasus (5\%), kecamatan Semarang Utara sebanyak 76 kasus (5\%), kecamatan Semarang Tengah sebanyak 67 kasus (4\%), kecamatan Gunungpati sebanyak 55 kasus (4\%), kecamatan Gajahmungkur sebanyak 51 kasus (3\%), kecamatan Gayamsari sebanyak 50 kasus (3\%), kecamatan Tugu 31 kasus (2\%), dan terakhir kecamatan Mijen sebanyak 30 kasus (2\%). Jumlah kasus COVID-19 tidak berbanding lurus dengan kepadatan penduduk pada tiap kecamatan bisa diakibatkan oleh beberapa faktor, salah satunya adalah masyarakat menerapkan perilaku 


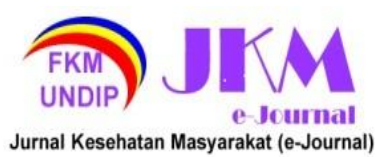

pencegahan COVID-19 dengan baik sesuai himbauan pemerintah.
JURNAL KESEHATAN MASYARAKAT (e-Journal)

Volume 10, Nomor 1, Januari 2022

ISSN: 2715-5617 / e-ISSN: 2356-3346

http://ejournal3.undip.ac.id/index.php/jkm

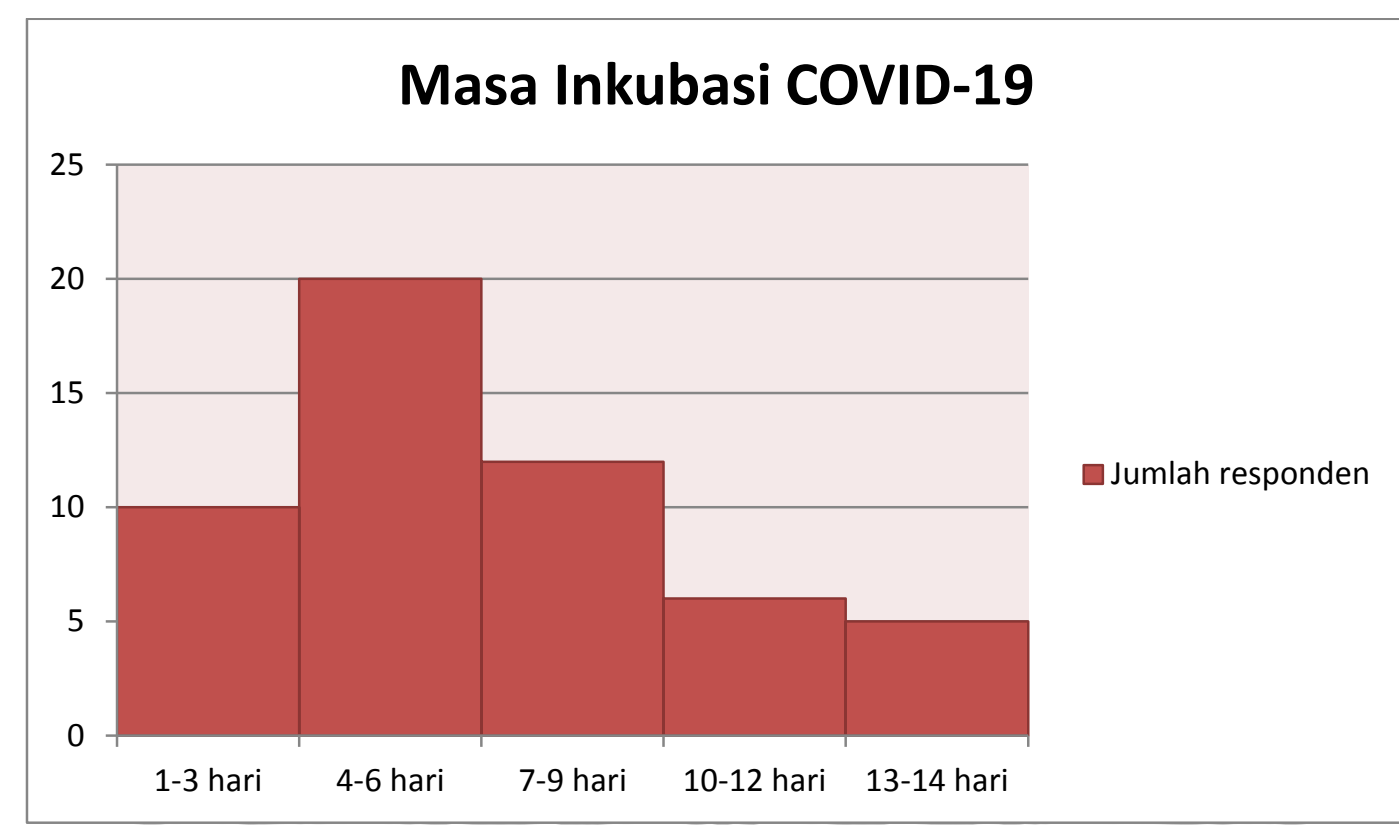

Gambaran Epidemiologi

Berdasarkan Karakteristik Waktu

Gambar 1. Masa Inkubasi COVID-19

Gambar di atas merupakan masa inkubasi COVID-19 di Kota Semarang. Masa inkubasi adalah selang waktu yang berlangsung antara pajanan terhadap patogen hingga gejala-gejala pertama kali muncul. Sehubungan dengan COVID19, masa inkubasi merupakan waktu yang diperlukan oleh patogen (SARS-CoV-2) untuk berlipatganda hingga dapat menimbulkan gejala pada inangnya. Berdasarkan tabel di atas, dapat diketahui rata-rata masa inkubasi COVID-19 adalah 4-6 hari.

\section{Gambaran Epidemiologi Berdasarkan Karakteristik Orang \\ Berdasarkan penelitian yang telah} dilakukan, diperoleh karakteristik subjek penelitian dapat dilihat dari tabel berikut:

Tabel 1 Karakteristik Subjek Penelitian

\begin{tabular}{llll}
\hline No. & \multicolumn{1}{c}{ Variabel } & N & $\%$ \\
\hline 1. & Usia & & \\
& $\geq 46$ tahun & 9 & 16,4 \\
& < 46 tahun & 46 & 83,6 \\
2. & Jenis kelamin & & \\
& Laki-laki & 33 & 60 \\
& Perempuan & 22 & 40 \\
\hline
\end{tabular}

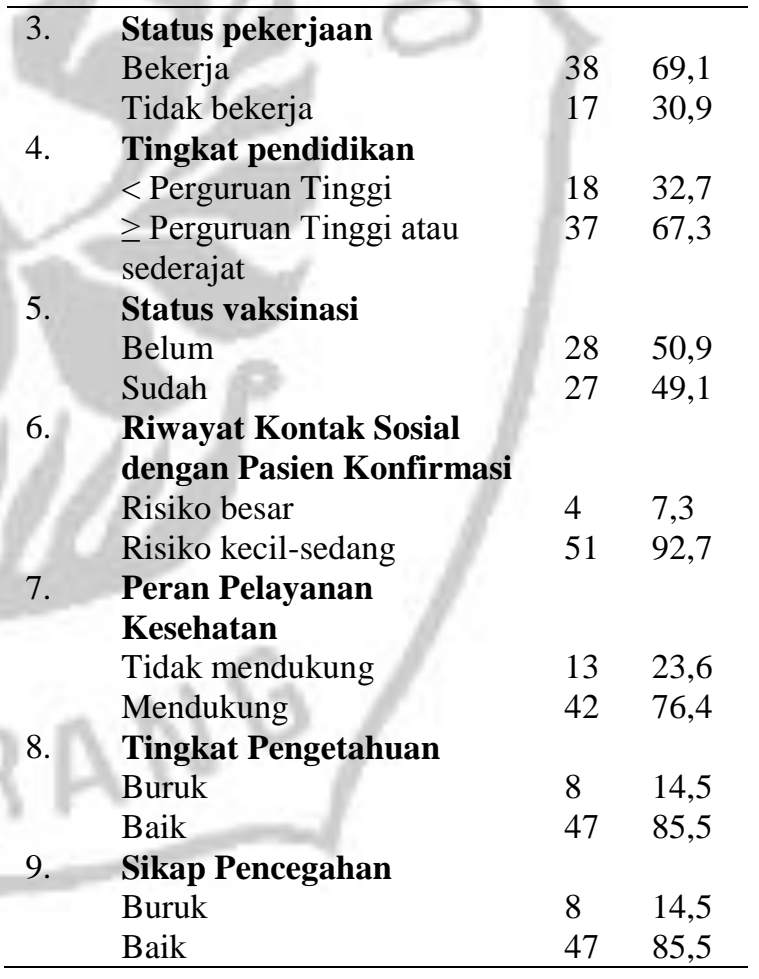

Tabel 2 Hasil Analisis Bivariat Hubungan Variabel Bebas dengan Variabel Terikat

\begin{tabular}{llcccl}
\hline No & Variabel Bebas & Nilai $\boldsymbol{p}$ & PR & CI 95\% & \multicolumn{1}{c}{ Hasil } \\
\hline 1. & Usia** & 0,42 & 1,70 & $0,71-4,10$ & Tidak ada hubungan \\
2. & Jenis kelamin & 0,04 & 2,89 & $0,93-8,96$ & Ada hubungan \\
3. & Status Pekerjaan** & 0,75 & 1,34 & $0,51-3,56$ & Tidak ada hubungan
\end{tabular}




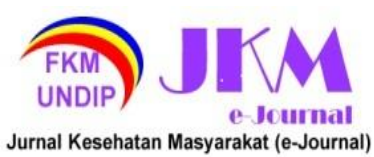

JURNAL KESEHATAN MASYARAKAT (e-Journal)

Volume 10, Nomor 1, Januari 2022

ISSN: 2715-5617 / e-ISSN: 2356-3346

http://ejournal3.undip.ac.id/index.php/jkm

\begin{tabular}{|c|c|c|c|c|}
\hline $\begin{array}{ll}\text { 4. } & \text { Tingkat } \\
& \text { Pendidikan }\end{array}$ & 0,08 & 2,90 & $0,86-9,77$ & Tidak ada hubungan \\
\hline $\begin{array}{l}\text { Tingkat } \\
\text { Pengetahuan** }\end{array}$ & $<0,01$ & 4,57 & $2,40-8,69$ & Ada hubungan \\
\hline $\begin{array}{l}\text { Sikap } \\
\text { Pencegahan** }\end{array}$ & 0,01 & 3,53 & $1,79-6,96$ & Ada hubungan \\
\hline $\begin{array}{l}\text { Peran Pelayanan } \\
\text { Kesehatan** }\end{array}$ & 0,17 & 1,94 & $0,87-4,31$ & Tidak ada hubungan \\
\hline Status Vaksinasi & 0,61 & 1,24 & $0,54-2,86$ & Tidak ada hubungan \\
\hline $\begin{array}{lr}\text { Riwayat } & \text { Kontak } \\
\text { Sosial } & \text { dengan } \\
\text { Pasien } & \text { COVID- } \\
19^{* *} & \end{array}$ & 0,31 & 1,46 & $1,21-1,75$ & Tidak ada hubungan \\
\hline
\end{tabular}

a. Usia Berdasarkan hasil penelitian dan perhitungan uji Fisher Exact didapatkan kesimpulan bahwa tidak ada hubungan antara usia dengan perilaku pencegahan COVID-19 di Kota Semarang. Hal ini sejalan dengan penelitian sebelumnya yang menyatakan bahwa usia tidak berhubungan dengan perilaku pencegahan COVID19 dikarenakan responden merasa beresiko terkena penyakit, mengingat bahwa COVID-19 dapat menyerang segala aspek usia, sehingga secara psikologis seseorang akan banyak melakukan tindakan pencegahan karena merasa lebih rentan terhadap penyakit. ${ }^{12}$ Penyebab lain yang menguatkan adalah tingkat kedisiplinan masingmasing individu yang berbeda, serta individu yang berusia lebih muda cenderung masih berada pada tahap pengembangan sikap disiplin dalam mengikuti protokol kesehatan yang juga dipengaruhi oleh komitmen kesadaran pada dirinya. Selain itu, individu dengan usia muda lebih membutuhkan pendampingan dalam menerapkan perilaku hidup bersih dan sehat melawan pandemi COVID-19. Pada situasi pandemi COVID-19 ini dibutuhkan kondisi psikologis yang baik untuk bisa menghadapi situasi yang kritis dan tetap waspada dengan menerapkan protokol kesehatan yang telah ditentukan untuk menghindari penularan penyakit ini.

\section{b. Jenis Kelamin}

Hasil analisis Chi Square pada penelitian ini didapatkan kesimpulan terdapat hubungan antara jenis kelamin dengan perilaku pencegahan COVID-19. Hasil bivariat didapatkan nilai Prevalence Ratio (PR) bernilai 2,89 dengan 95\% $\mathrm{CI}=0,93-8,96$ yang berarti bahwa responden dengan jenis kelamin laki-laki mempunyai risiko 2,89 kali lebih besar memiliki perilaku pencegahan buruk terkait COVID-19 daripada responden berjenis kelamin perempuan. Dengan adanya perilaku pencegahan yang buruk, jenis kelamin laki-laki akan mudah terkena COVID-19 dibandingkan perempuan. Penelitian lain yang juga membuktikan adanya hubungan antara jenis kelamin dengan perilaku pencegahan dilakukan

oleh Sari et al., (2020) dengan $p$ value $=0,001$. Teori Green mengatakan bahwa jenis kelamin termasuk faktor predisposisi atau faktor pemungkin yang memberikan kontribusi pada perilaku kesehatan seseorang. Jenis kelamin laki-laki cenderung kurang peduli terhadap kondisi lingkungan dan kesehatannya. ${ }^{13}$ Laki-laki mempunyai kecenderungan berperilaku kurang baik dibandingkan perempuan. Fenomena ini menghasilkan laki-laki yang kurang peduli terhadap kondisi lingkungan dan kesehatannya. Kasus kematian COVID-19 di Indonesia di dominasi oleh jenis kelamin laki-laki. Hal ini diduga terkait perilaku pencegahan penularan COVID-19 laki-laki lebih buruk dibandingkan perempuan.

\section{c. Status Pekerjaan}

Berdasarkan hasil penelitian dan perhitungan Fisher Exact, didapatkan kesimpulan bahwa tidak ada hubungan antara status pekerjaan dengan perilaku pencegahan COVID-19 di Kota Semarang dengan nilai signifikasi 0,75 ( $p>0,05)$. $\mathrm{Hal}$ ini sejalan dengan penelitian Sari et al., (2020) bahwa tidak ada hubungan antara status pekerjaan dengan perilaku pencegahan COVID-19 yang disebabkan karena antara responden yang bekerja dan tidak bekerja dengan perilaku pencegahan COVID-19 yang baik jumlahnya hampir sama. Hal tersebut dapat dikarenakan bahwa perilaku seseorang tidak hanya dipengaruhi oleh pekerjaan saja, akan tetapi banyak faktor lain seperti pengetahuan, persepsi, motivasi, dan lainnya yang dapat mempengaruhi seseorang untuk melakukan perilaku pencegahan. ${ }^{6}$ Status pekerjaan tidak berhubungan dengan perilaku pencegahan COVID19 kemungkinan dikarenakan responden melakukan pencegahan COVID-19 walaupun mereka tidak bekerja.

\section{d. Tingkat Pendidikan}

Berdasarkan hasil penelitian dan perhitungan uji Chi Square, didapatkan kesimpulan bahwa tidak ada hubungan antara tingkat pendidikan dengan perilaku pencegahan COVID19 di Kota Semarang dengan nilai signifikasi 0,08 $(p>0,05)$. Penelitian ini sejalan dengan penelitian 


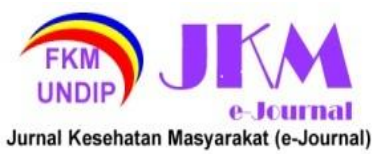

yang dilakukan sebelumnya oleh Sari bahwa tidak ada hubungan yang signifikan antara tingkat pendidikan dengan perilaku pencegahan. ${ }^{14} \mathrm{Hal}$ ini disebabkan karena pengetahuan yang didapatkan oleh masyarakat mengenai pencegahan COVID-19 tidak hanya didapatkan dari pendidikan formal, melainkan dari pengalaman dirinya maupun lingkungan kehidupan bermasyarakat. Penelitian terdahulu juga menyebutkan bahwa tingkat pendidikan tidak mempengaruhi seseorang dalam berperilaku pencegahan dikarenakan oleh beberapa komponen seperti perbedaan persepsi mengenai kerentanan penyakit, persepsi dalam upaya pencegahan, persepsi tentang manfaat, serta persepsi individu tersebut untuk melakukan upaya pencegahan. ${ }^{15}$

\section{e. Tingkat Pengetahuan}

Berdasarkan hasil penelitian dan perhitungan uji Fisher Exact, didapatkan kesimpulan bahwa ada hubungan antara tingkat pengetahuan dengan perilaku pencegahan COVID19 di Kota Semarang dengan nilai $p$ value $=<0,01$ dan nilai PR CI 95\% 4,57 (2,40-8,69). Penelitian ini sejalan dengan penelitian yang dilakukan oleh Sari dengan $\mathrm{p}$ value $=0,001 ; \mathrm{p}<0,05^{14}$ dan penelitian yang dilakukan oleh Hidayani dengan nilai signifikasi $\mathrm{p}=0,024 ; \mathrm{p}<0,05 .{ }^{16}$ Penelitian lain yang membuktikan adanya hubungan antara tingkat pengetahuan dengan perilaku pencegahan COVID19 dilakukan oleh Purba, dkk (2021) yang meneliti pada 301 responden dengan nilai signifikasi $\mathrm{p}$ value $=0,001$ dengan POR CI 95\% 2,20 (1,38-3,51). Penelitian sebelumnya yang dilakukan di Saudi Arabia, menunjukkan bahwa pengetahuan tinggi peserta tentang COVID-19 mudah diinterpretasikan menjadi perilaku pencegahan yang baik dan aman selama pandemi COVID-19. Hampir 95\% responden menahan diri untuk menghadiri acara sosial, 94\% menghindari tempat keramaian, dan $88 \%$ menghindari berjabat tangan. Responden mengadopsi praktik yang baik dan aman. Materi pendidikan dan sosialisasi untuk meningkatkan pengetahuan terbukti berpengaruh dalam perubahan perilaku pencegahan. ${ }^{17}$ Mengingat bahwa faktor pengetahuan merupakan faktor penting yang berhubungan dengan perilaku pencegahan COVID19, dibuktikan dengan mayoritas responden yang dilakukan peneliti dengan tingkat pengetahuan yang baik dengan perilaku pencegahan baik sebanyak 38 orang $(80,9 \%)$.

\section{f. Sikap Pencegahan}

Berdasarkan hasil penelitian dan perhitungan uji Fisher Exact, didapatkan kesimpulan bahwa ada hubungan antara sikap pencegahan dengan perilaku pencegahan COVID19 di Kota Semarang dengan nilai $\mathrm{p}$ value $=0,01$ dan PR 3,53 CI 95\%: 1,79-6,96. Sikap pencegahan berhubungan dengan perilaku pencegahan juga dibuktikan dari penelitian Sari dengan nilai signifikasi 0,$00 ; \mathrm{p}<0,05$ pada pegawai Kantor BKKBN Pusat. ${ }^{14}$ Penelitian lain yang juga sejalan dilakukan oleh Rayhana \& Triana (2016) yang menyatakan bahwa terdapat hubungan yang bermakna antara sikap tentang PHBS dengan perilaku hidup bersih dan sehat dengan $\mathrm{p}$ value 0,001. ${ }^{18}$ Penelitian mengenai hubungan sikap pencegahan dan perilaku pencegahan juga dilakukan oleh Purba yang menyatakan ada hubungan antara sikap pencegahan dengan perilaku pencegahan $(\mathrm{p}<0,05) .{ }^{19}$ Perlu diketahui bahwa sikap merupakan salah satu faktor predisposisi (faktor pemungkin) ketika seseorang melakukan perilaku tertentu. Dalam pencegahan penyakit, sikap merupakan salah satu faktor yang mempengaruhi masyarakat untuk mencegah terjadinya wabah penyakit, karena dalam upaya pencegahan penyakit pasti dikaitkan dengan sikap masyarakat. Perilaku hidup bersih dan sehat merupakan bagian dari perilaku pencegahan penularan COVID-19. Sikap merupakan faktor yang penting dalam pembentukan perilaku seseorang, sehingga perilaku baik atau buruk akan dipengaruhi oleh sikap. Dalam penelitian ini, terdapat 6 orang $(75 \%)$ dengan sikap pencegahan buruk yang memiliki perilaku pencegahan yang buruk pula. Sementara itu, 37 orang $(78,7 \%)$ dengan sikap pencegahan baik memiliki perilaku pencegahan yang baik pula. Hal ini menunjukkan, sikap pencegahan yang baik akan membentuk perilaku pencegahan COVID-19 yang baik, begitupun sebaliknya.

\section{g. Peran Pelayanan Kesehatan}

Berdasarkan hasil penelitian dan perhitungan uji Fisher Exact, didapatkan kesimpulan bahwa tidak ada hubungan antara peran pelayanan kesehatan dengan perilaku pencegahan COVID-19 di Kota Semarang dengan nilai signifikasi $0,17 \quad(p>0,05)$. Penelitian ini sejalan dengan penelitian yang dilakukan oleh Purba dengan nilai $\mathrm{p}$ value $=0,683(\mathrm{p}>0,05)$ sehingga tidak ada hubungan antara peran tenaga kesehatan dengan perilaku pencegahan COVID-19. ${ }^{19}$ Berdasarkan penelitian terdahulu, dukungan petugas kesehatan tidak berhubungan dengan perilaku pencegahan COVID-19 pada ibu hamil yang mana responden mengutarakan bahwa jenis dukungan berupa informasional dimana petugas kesehatan tidak memberikan informasi tentang cara mencuci tangan dengan baik dan benar pada responden. ${ }^{20}$ Dukungan tenaga kesehatan adalah kenyamanan fisik dan psikologis, perhatian, penghargaan, maupun bantuan dalam bentuk lainnya yang diterima individu dari tenaga kesehatan. Pada penelitian yang dilakukan oleh penulis, peran pelayanan kesehatan yang dimaksud adalah dalam bentuk pemberian pelayanan 


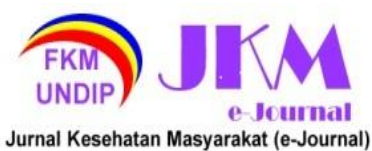

perawatan, pemeriksaan, dan pengobatan secara cepat dan tepat serta memberikan promosi kesehatan mengenai pencegahan COVID-19 secara rutin.

\section{h. Status Vaksinasi}

Berdasarkan hasil penelitian dan perhitungan uji Chi Square, didapatkan nilai $\mathrm{p}$ value $=0,61$ sehingga dapat disimpulkan bahwa tidak ada hubungan antara status vaksinasi dengan perilaku pencegahan COVID-19 di Kota Semarang dengan nilai signifikasi 0,61 ( $>>0,05)$. Pada penelitian ini, diketahui 28 orang $(50,9 \%)$ belum melakukan vaksinasi dan 27 orang $(49,1 \%)$ sudah melakukan vaksinasi. Berdasarkan alasannya, responden mengaku belum melakukan vaksinasi dikarenakan beberapa hal, seperti takut, memiliki keterbatasan biaya, tidak percaya pada vaksin yang beredar, sedang positif COVID-19, dan lain-lain. Diketahui bahwasannya vaksin yang saat ini beredar seperti Sinovac dan Astra-Zeneca merupakan vaksin yang mampu menurunkan risiko tertular COVID-19, meringankan gejala apabila terkena COVID-19, mengurangi risiko kematian akibat COVID-19, dan masih banyak lagi.

\section{i. Riwayat Kontak Sosial dengan Pasien} Konfirmasi

Berdasarkan hasil penelitian dan perhitungan uji Fisher Exact, didapatkan kesimpulan bahwa tidak ada hubungan antara riwayat kontak sosial dengan pasien konfirmasi dengan perilaku pencegahan COVID-19 di Kota Semarang dengan nilai signifikasi 0,31 ( $p>0,05){ }^{21}$ Pada penelitian lain, didapatkan hasil yang tidak signifikan antara status risiko terhadap ketaatan seseorang melawan COVID-19, disebabkan oleh kemampuan virus tersebut memiliki daya tular yang sangat mudah dan berbeda dibanding virus lainnya dan semua orang berisiko karena penyebarannya dapat melalui percikan droplet yang ukurannya sangat kecil dari orang yang terinfeksi. ${ }^{22}$ Penelitian ini menunjukkan mayoritas responden $(92,7 \%)$ memiliki risiko kecil-sedang mengenai riwayat kontak sosial dengan pasien konfirmasi untuk terpapar infeksi COVID-19. Hal tersebut didasarkan atas beberapa faktor, meliputi perilaku keluar rumah/tempat umum yang meliputi banyak orang, penggunaan transportasi umum, melakukan perjalanan ke luar kota/internasional/wilayah yang dinyatakan sebagai zona hitam/merah, mengikuti kegiatan yang melibatkan banyak orang, memiliki riwayat kontak dengan pasien konfirmasi, sedang mengalami demam, batuk, pilek, gangguan pernafasan dan gejala-gejala umum COVID-19.

Tabel 3. Rekapitulasi Analisis Multivariabel

\begin{tabular}{|c|c|c|c|c|c|}
\hline Langkah & No. & Variabel & Wald & Nilai $p$ & $\operatorname{Exp}(B) / O R$ \\
\hline \multirow[t]{5}{*}{ Langkah 1} & 1. & Jenis kelamin & 3,576 & 0,059 & 14,116 \\
\hline & 2. & Tingkat pendidikan & 1,174 & 0,279 & 2,605 \\
\hline & 3. & Tingkat pengetahuan & 6,490 & 0,011 & 72,652 \\
\hline & 4. & Sikap pencegahan & 5,202 & 0,023 & 18,502 \\
\hline & 5. & Peran pelay & 8,164 & 0,458 & 0,307 \\
\hline \multirow[t]{4}{*}{ Langkah 2} & 1. & Jenis kelamin & 3,622 & 0,057 & 11,310 \\
\hline & 2. & Tingkat pendidikan & 1,742 & 0,187 & 3,104 \\
\hline & 3. & Tingkat pengetahuan & 7,568 & 0,006 & 36,343 \\
\hline & 4. & Sikap pencegahan & 5,168 & 0,023 & 13,917 \\
\hline \multirow[t]{3}{*}{ Langkah 3} & 1. & Jenis kelamin & 4,035 & 0,045 & 10,996 \\
\hline & 2. & Tingkat pengetahuan & 7,212 & 0,007 & 39,474 \\
\hline & 3. & Sikap pencegahan & 4,699 & 0,030 & 10,099 \\
\hline
\end{tabular}

Variabel terkuat untuk terjadinya perilaku pencegahan COVID-19 adalah tingkat pengetahuan. Hal ini dikarenakan variabel sikap pencegahan memiliki nilai $\mathrm{p}$ paling kecil $(0,007)$ dan nilai Wald yang paling besar $(7,212)$ di antara variabel lain. Jadi, probabilitas pasien konfirmasi aktif COVID-19 yang berperilaku pencegahan buruk dengan faktor jenis kelamin laki-laki, tingkat pengetahuan buruk, dan sikap pencegahan buruk sebesar $99 \%$.

\section{KESIMPULAN}

Gambaran epidemiologi kasus COVID-19 di Kota Semarang berdasarkan karakteristik orang;

a. Responden dengan jenis kelamin laki-laki lebih banyak (60\%) dibanding perempuan $(40 \%)$

b. Menurut usia, responden dengan usia remaja hingga dewasa ( $<46$ tahun) lebih banyak $(83,6 \%)$ dibanding usia lansia ( $\geq 46$ tahun) $(16,4 \%)$

c. Menurut status pekerjaan, orang yang bekerja $(69,1 \%)$ dan tidak bekerja $(30,9 \%)$ memiliki risiko yang sama terkena COVID-19 


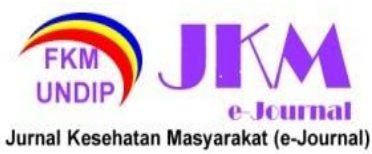

karena ada kemungkinan responden samasama melakukan pencegahan COVID-19 walaupun mereka tidak bekerja.

2. Gambaran epidemiologi kasus COVID-19 di Kota Semarang berdasarkan karakteristik tempat, 5 kasus tertinggi hingga terendah berturut-turut pada kecamatan Pedurungan, kecamatan Tembalang, kecamatan Semarang Barat, kecamatan Banyumanik, dan kecamatan Ngaliyan.

3. Gambaran epidemiologi kasus COVID-19 di Kota Semarang berdasarkan karakteristik waktu, rata-rata masa inkubasi COVID-19 adalah 4-6 hari.

4. Faktor yang berhubungan perilaku pencegahan COVID-19, yaitu: jenis kelamin, tingkat pengetahuan, dan sikap pencegahan.

5. Faktor yang tidak berhubungan dengan perilaku pencegahan COVID-19, yaitu: usia, status pekerjaan, tingkat pendidikan, peran pelayanan kesehatan, status vaksinasi, riwayat kontak sosial dengan pasien COVID-19.

\section{SARAN}

1. Untuk Dinas Kesehatan Kota Semarang

a. Dinas Kesehatan bekerja sama dengan Puskesmas mengadakan program promosi kesehatan secara terorganisir dan menyeluruh di wilayah Kota Semarang guna memutus rantai persebaran COVID-19.

b. Dinas Kesehatan bekerja sama dengan Puskesmas dan Perangkat Desa guna memaksimalkan program vaksinasi gratis di Semarang secara menyeluruh guna mengurangi risiko terkena COVID-19.

c. Dinas Kesehatan bekerja sama dengan Puskesmas melakukan testing dan tracing secara menyeluruh di tempat fasilitas umum seperti pasar dengan tujuan memutus rantai persebaran COVID-19.

2. Untuk Masyarakat Umum

a. Selalu menerapkan protokol kesehatan 5M (Mencuci tangan, menggunakan masker, menjaga jarak, menjauhi kerumunan, mengurangi mobilitas)

b. Selalu update mengenai informasi COVID-19 dengan sumber yang terpercaya

c. Ikut mendukung program yang dilaksanakan oleh Pemerintah, yaitu vaksinasi guna mengurangi risiko COVID-19.

3. Untuk Peneliti Selanjutnya

a. Bagi peneliti selanjutnya diharapkan dapat menambah variabel lain yang belum diteliti seperti tingkat ekonomi, menambah pertanyaan yang lebih kompleks mengenai perilaku pencegahan COVID-19. Peneliti selanjutnya juga dapat memperluas cakupan penelitian ke masyarakat umum di Kota Semarang.

\section{DAFTAR PUSTAKA}

1. Li, Q., Med, M., Guan, X., \& All, E. Early Transmission Dynamics in Wuhan, China, of Novel Coronavirus-Infected Pneumonia. The New England Journal of Medicine, 382(December 2019), 2020; 1199-1207. https://doi.org/10.1056/NEJMoa2001316

2. Kemenkes. Pedoman Pencegahan Pengendalian COVID-19 revisi V. Jakarta; 2020a.

3. WHO. SURVEY TOOL AND GUIDANCE Rapid, Simple, Flexible Behavioural Insights on COVID-19. In WHO Europe Guideline; 2020.

4. DKK, S. Informasi Coronavirus (COVID-19) Semarang; 2020. Retrieved from https://siagacorona.semarangkota.go.id/halama n/odppdpv2

5. Peng, Y., Pei, C., Zheng, Y., Wang, J., Zhang, K., Zheng, Z., \& Zhu, P. A cross-sectional survey of knowledge, attitude and practice associated with COVID-19 among undergraduate students in China. BMC Public Health, 2020; 20.

6. Notoatmodjo, S. Ilmu Perilaku Kesehatan 2nd edition. Jakarta: Rineke Cipta; 2014.

7. Widayati, A., Suryawati, S., Crespigny, C. De, \& Hiller, J. E. Knowledge and beliefs about antibiotics among people in Yogyakarta City Indonesia : a cross sectional population-based survey. Antimicrobial Resistance and Infection Control, 2012; 1, 1-7.

8. Nasional, K. P. C. -19 dan P. E. Vaksin COVID-19 Efektif Meski Virus COVID-19 Bermutasi. Covid19.Go.Id; 2021.

9. Prihati, D. R., Wirawati, M., \& Supriyanti, E. Analisis Pengetahuan Dan Perilaku Masyarakat Di Kelurahan Baru Kotawaringin Barat Tentang Covid 19. Malahayati Nursing Journal, 2(September), 2020; 780-790.

10. Shamshiripour, A., Rahimi, E., Shabanpour, R., \& Mohammadian, A. K. Transportation Research Interdisciplinary Perspectives How is COVID-19 reshaping activity-travel behavior? Evidence from a comprehensive survey in Chicago. Transportation Research Interdisciplinary Perspectives, 2020; 7 , 100216. https://doi.org/10.1016/j.trip.2020.100216

11. WHO. WHO Coronavirus (COVID-19) Dashboard. 2021. Retrieved from https://covid19.who.int/table

12. Putri, N. S., \& Nazmi, A. N. The Analysis of Students Health Behavior Factors to Prevent Covid-19. International Journal of Nursing 


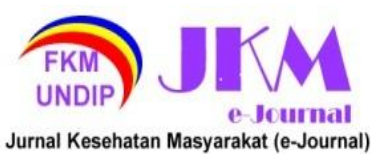

and Health Services (IJNHS), 2021; 4(2), 223230.

13. Sari, A. R., Rahman, F., Wulandari, A., Pujianti, N., Laily, N., Anhar, Y., ... Muddin, I. Perilaku Pencegahan Covid-19 Ditinjau dari Karakteristik Individu dan Sikap Masyarakat. Jurnal Penelitian Dan Pengembangan Kesehatan Masyarakat Indonesia, 2020; 1(128), 32-37.

14. Sari, A., \& Budiono, I. Faktor yang Berhubungan dengan Perilaku Pencegahan Penularan COVID-19. Indonesian Journal of Public Health and Nutrition, 2021; 1(1), 5061.

15. Pratiwi, M. S. A., Yani, M. V. W., Putra, A. I. Y., \& All, E. Hubungan Karakteristik Individu terhadap Perilaku Mengenai Pandemi COVID19 di Desa Gulingan, Mengwi, Bali. Jurnal Kesehatan, 2020; 13(2), 112-120. https://doi.org/10.24252/kesehatan.v1i1.16340

16. Hidayani, W. R. Faktor Faktor Risiko yang Berhubungan dengan COVID 19: Literature Review. Jurnal Untuk Masyarakat Sehat (JUKMAS), 2020; 4(2), 120-134.

17. Al-hanawi, M. K., Angawi, K., Alshareef, N., \& Qattan, A. M. Knowledge, Attitude and Practice Toward COVID-19 Among the Public in the Kingdom of Saudi Arabia: A CrossSectional Study. Frontiers in Public Health, 8(May), 2020; 1-10. https://doi.org/10.3389/fpubh.2020.00217

18. Rayhana, \& Triana, R. A. Hubungan Karakteristik, Pengetahuan dan Sikap terhadap Perilaku Hidup Bersih dan Sehat pada Ibu Rumah Tangga di Kelurahan Kebalen Kecamatan Babelan Bekasi Utara Tahun 2016. Jurnal Kedokteran Dan Kesehatan, 2016; 12(2).

19. Purba, C. V. G., Nurhapipa, Priwahyuni, Y., Alamsyah, A., \& Ikhtiaruddin. Analisis Faktor Perilaku Pencegahan COVID-19 pada Mahasiswa Sekolah Tinggi Ilmu Kesehatan Hang Tuah Pekanbaru Tahun 2020. Jurnal Kesehatan Masyarakat \& Gizi, 2021; 3(2). https://doi.org/10.35451/jkg.v3i2.562

20. Sari, L. N. I., \& Budiono, I. Perilaku Pencegahan Penularan COVID-19 pada Ibu Hamil. Indonesia Journal of Public Health and Nutrition, 1(1), 2021; 124-132. https://doi.org/10.15294/ijphn.v1i1.45433

21. Decaprio, D., Gartner, J., Mccall, C. J., Burgess, T., Garcia, K., Kothari, S., \& Sayed, S. Building a COVID-19 vulnerability index. Journal of Medical Artifical Intelligence, 2019; (1), 1-10. https://doi.org/10.21037/jmai20-47

22. Jin, Y., Cai, L., Cheng, Z., Cheng, H., Deng, T., Fan, Y., ... Lin, L.. A Rapid Advice
Guideline for The Diagnosis and Treatment of 2019 Novel Coronavirus ( 2019-nCoV ) Infected Pneumonia (standard version ). Military Medical Research, 2019; 7(4), 1-23. 